\title{
Pengaruh Lingkungan Kerja dan Motivasi Terhadap Kepuasan Kerja dan Dampaknya terhadap Kinerja Pegawai pada Kantor Pertanahan Kabupaten Merangin Provinsi Jambi
}

\author{
${ }^{1}$ Kartono Agustiyanto, ${ }^{2}$ Tety Asnawi, ${ }^{3}$ Susilawati \\ ${ }^{1}$ Mahasiswa Magister Manajemen Universitas Batanghari Jambi, Indonesia \\ ${ }^{2,3}$ Dosen Fakultas Ekonomi Universitas Batanghari Jambi, Indonesia
}

\begin{abstract}
The purpose of this research are to knowing, analyze, and reviewing the influence of work environment and motivation on job satisfaction and impact on employee performance at Land Office, Regency of Merangin, Jambi Province. The analysis method used are descriptive analysis and verification analysis. Descriptive analysis is used to reveal the facts of the object that have been research. While verification analysis is used to test and measure the influence of independent variable X1 (Work Environment) and X2 (Motivation) to the dependent variable Z (Performance) with intervening variable Y(Job Satisfaction). The result of this research and hypothesis testing that have been conducted got the result that : 1) Effect of work environment on job satisfaction directly and indirectly is 9,001\%; 2) The influence of motivation on job satisfaction directly and indirectly is 69,739\%; 3) Effect of work environment and joint motivation to job satisfaction is 78,740\%; 4) The effect of working environment on the performance directly and indirectly is $-1,945 \%$; 5) The influence of motivation on performance directly and indirectly is 15,639\%; 6) The influence of working environment and joint motivation on performamce is 13,693\%; 7) The effect of job satisfaction on performance is $15,682 \%$; 8) The influence of working environment and joint motivation on performance through job satisfaction is $14,009 \%$.
\end{abstract}

Keywords : Work Environment, Motivation, Job Satisfaction, Performance

\section{PENDAHULUAN}

Setiap lembaga atau instansi, senantiasa berupaya untuk mencapai tujuan yang telah ditetapkan. Untuk mencapai tujuan tersebut, maka suatu lembaga atau instansi memerlukan aset yang dapat menunjang keberhasilannya, yakni sumber daya menusia yang mempunyai posisi yang strategis dan dominan dalam menentukan berhasil tidaknya suatu lembaga atau instansi dalam mencapai tujuannya. Sumber daya manusia mempunyai peran yang sangat penting dalam rangka penyelenggaraan pemerintahan karena merupakan komponen utama yang melaksanakan tugas pelayanan publik. Untuk menjamin pelayanan yang berkualitas dibutuhkan kinerja para pegawai yang memiliki kemampuan di bidangnya. Kinerja merupakan cerminan dari optimalnya aktivitas para anggota organisasi (pegawai) pada suatu instansi. Semakin tidak optimal para pegawai dalam melakukan aktivitasnya, maka akan semakin rendah pula kinerja instansi secara keseluruhan, sebaliknya apabila para pegawai bekerja secara optimal maka akan tinggi pula kinerja instansi secara keseluruhan.

Terminologi sumber daya manusia merujuk kepada orang-orang di dalam organisasi. Menurut Simamora (2006) manajemen sumber daya merupakan proses pendayagunaan bahan baku dan sumber daya manusia untuk mencapai tujuan yang ditetapkan. Menurut Mangkunegara (2010) kinerja adalah hasil kerja secara kualitas dan kuantitas yang dapat dicapai oleh seorang pegawai dalam melaksanakan tugas sesuai dengan tangung jawab yang diberikan kepadanya. Kepuasan kerja merupakan perasaan seseorang terhadap pekerjaan, ini berarti bahwa konsep kepuasan kerja semacam ini melihat kepuasan kerja itu sebagai interaksi manusia di lingkungan kerjanya. Menurut Sedarmayanti (2001) lingkungan kerja merupakan alat perkakas dan bahan yang dikerjakan, lingkungan sekitar tempat pegawai bekerja, metode kerja, serta pengaturan kerjanya baik sebagai perseorangan maupun sebagai kelompok. Motivasi merupakan keseluruhan proses pemberian dorongan/rangsangan kepada para karyawan sehingga mereka bersedia bekerja dengan rela tanpa dipaksa.

Motivasi merupakan dorongan, keinginan, hasrat dan tenaga penggerak yang berasal dari diri manusia untuk berbuat atau untuk melakukan sesuatu. Jadi pada dasarnya apabila organisasi/instansi ingin meraih kinerja yang optimal sesuai dengan target yang telah ditentukan maka harus memberikan motivasi pada pegawai agar pegawai mau dan rela mencurahkan tenaga dan fikiran yang dimiliki demi pekerjaan. 
Memotivasi pegawai tidak mudah karena dalam diri pegawai terdapat keinginan, kebutuhan dan harapan yang berbeda antara satu pegawai dengan pegawai lain. Jika dapat memahami persoalan motivasi dan mengatasinya maka organisasi/instansi akan mendapatkan pegawai yang optimal sesuai dengan standar yang ditentukan.

Dalam bekerja di suatu instansi, maka para pegawai masing-masing mempunyai kebutuhan yang bersifat fisik maupun non fisik yang harus dapat memenuhi kebutuhan hidup yang layak. Apabila kebutuhan pegawai sudah terpenuhi dengan imbalan yang pantas dari hasil kerjanya, maka kepuasan kerja pegawai akan meningkat. Kinerja pegawai juga tidak terlepas dari kepuasan kerja pegawai itu sendiri. Pegawai merasakan adanya rasa keadilan terhadap gaji yang diterima sehubungan dengan pekerjaan yang dilakukannya. Kepuasan gaji disini dapat diartikan bahwa seseorang akan terpuaskan dengan gajinya apabila persepsi terhadap gaji yang diperoleh sesuai dengan yang diharapkan. Pegawai yang merasa terpuaskan akan cenderung bertahan didalam organisasi/instansi tersebut dan dapat meningkatkan kinerja yang berarti tujuan organisasi/instansi dapat tercapai. Sebaliknya, ketidakpuasan kerja seorang pegawai akan menimbulkan berbagai masalah, seperti meningkatnya tingkat absen pegawai, perilaku kerja pasif, serta dapat merusak atau mengganggu kinerja pegawai lain.

Kinerja seseorang merupakan kombinasi dari kemampuan, usaha dan kesempatan yang dapat dinilai dari hasil kerjanya. Hasibuan (2008) mengemukakan kinerja (prestasi kerja) adalah suatu hasil kerja yang dicapai seseorang yang didasarkan atas kecakapan, pengalaman dan kesungguhan serta waktu. Kinerja dipengaruhi beberapa faktor diantaranya adalah kuantitas pekerjaan yang dapat dilakukan oleh seseorang dalam waktu satu hari kerja, kualitas dalam ketaatan prosedur dan disiplin, keandalan dalam melakukan pekerjaan yang diisyaratkan dengan supervisi minimum, kehadiran masuk kerja setiap hari dan sesuai jam kerja, dan kemampuan bekerja sama dengan orang lain dalam menyelesaikan tugas dan pekerjaan yang telah ditetapkan sehingga mencapai daya guna yang sebesar-besarnya. Tujuan penelitian ini adalah untuk mengetahui dan menganalisis pengaruh lingkungan kerja dan motivasi melalui kepuasan kerja terhadap kinerja pegawai pada Kantor Pertanahan Kabupaten Merangin.

\section{Landasan Teori dan Hipotesis Lingkungan Kerja}

Lingkungan kerja adalah segala sesuatu yang berada disekitar karyawan yang mempengaruhi dirinya dalam menjalankan dan menyelesaikan tugas-tugas yang diberikan kepadanya dalam suatu wilayah (Sofyandi, 2008). Lingkungan kerja adalah segala sesuatu yang ada disekitar pekerja yang dapat mempengaruhi dalam bekerja meliputi pengaturan penerangan, pengontrolan suara gaduh, pengaturan kebersihan tempat kerja dan pengaturan keamanan tempat kerja. Notoatmodjo (2009), menjelaskan bahwa lingkungan kerja adalah semua faktor fisik, psikologis, sosial jaringan dan hubungan yang berlaku dalam organisasi dan terpengaruh terhadap pegawai. Lingkungan kerja didalam organisasi dapat dibagi menjadi beberapa bagian atau aspek pembentuk lingkungan kerja yang lebih terperinci. Menurut Sedarmayanti (2001), ada beberapa indikator yang dapat digunakan dalam tolok ukur lingkungan kerja, antara lain sebagai berikut (1) penerangan; (2) suhu udara; (3) suara bising; (4) penggunaan warna; (5) ruang gerak yang diperlukan; (6) Keamanan kerja; dan (7) hubungan sesama rekan kerja

\section{Motivasi}

Menurut Hasibuan (2008), motivasi kerja karyawan dipengaruhi oleh kebutuhan fisik, kebutuhan akan keamanan dan keselamatan, kebutuhan sosial, kebutuhan akan penghargaan diri, dan kebutuhan perwujudan diri. Kemudian dari faktor kebutuhan tersebut diturunkan menjadi indikator-indikator untuk mengetahui tingkat motivasi kerja pada karyawan, yaitu ;

1. Kebutuhan fisik, ditunjukkan dengan pemberian gaji yang layak kepada pegawai, pemberian bonus, uang makan, uang transport, fasilitas perumahan, dan lain sebagainya.

2. Kebutuhan rasa aman dan keselamatan, ditunjukkan dengan fasilitas keamanan dan keselamatan kerja yang diantaranya seperti adanya jaminan sosial tenaga kerja, dana pensiun, tunjangan kesehatan, asuransi kecelakaan, dan perlengkapan keselamatan lainnya. 
3. Kebutuhan sosial, ditunjukkan dengan melakukan interaksi dengan orang lain yang diantaranya dengan menjalin hubungan kerja yang harmonis, kebutuhan untuk mencintai dan dicintai.

4. Kebutuhan akan penghargaan, ditunjukkan oleh pengakuan kebutuhan akan penghargaan, berdasarkan kemampuannya, yaitu kebutuhan untuk dihormati dan dihargai karyawan lain dan pimpinan terhadap prestasi kerjanya.

5. Kebutuhan perwujudan diri, ditunjukkan dengan sifat pekerjaan yang menarik dan menantangl, dimana karyawan tersebut akan mengerahkan kecakapan, kemampuan, keterampilan dan potensinya. Dalam pemenuhan kebutuhan ini dapat dilakukan oleh perusahaan dengan menyelenggarakan pendidikan dan pelatihan.

\section{Kepuasan Kerja}

Handoko (2001) menyatakan bahwa kepuasan kerja adalah keadaan emosional yang menyenangkan atau tidak menyenangkan dengan mana para karyawan memandang pekerjaan mereka. Indikator yang digunakan dalam penelitian ini yaitu: (1) The work it self (pekerjaan itu sendiri); (2) Pay (gaji); (3) Promotion Opportunity (kesempatan promosi); (4) Supervision (atasan); (5) Co-worker (rekan kerja); (6) Working condition (kondisi kerja) (Adisetiawan, 2014)

\section{Kinerja}

Kinerja pada dasarnya merupakan hasil kerja yang dihasilkan oleh pegawai atau perilaku nyata yang ditampilkan sesuai dengan perannya dalam organisasi. Hasil kerja pegawai merupakan suatu hal yang sangat penting dalam usaha organisasi untuk mencapai tujuannya, sehingga berbagai kegiatan harus dilakukan organisasi untuk meningkatkannya. Salah satunya adalah melalui penilaian hasil kerja, yaitu suatu proses organisasi dalam menilai hasil kerja pegawainya. Selanjutnya Sedarmayanti (2001) menyatakan ada beberapa dimensi yang harus diikuti dalam penilaian kinerja yaitu: (1) Quantity of work (banyaknya pekerjaan); (2) Quality of work (kualitas pekerjaan); (3) Job knowledge (pengetahuan tentang pekerjaan); (4) Creativeness (kreativitas); (5) Coorperation (kerjasama); (6) Dependability (dapat diandalkan/kemandirian); (7) Initiative (inisiatif); dan (8) Personal qualities (kualitas pribadi). (Adisetiawan, 2013)

\section{Hipotesis}

Hipotesis dalam penelitian ini adalah diduga lingkungan kerja dan motivasi melalui kepuasan kerja berpengaruh signifikan terhadap kinerja pegawai pada Kantor Pertanahan Kabupaten Merangin.

\section{METODE PENELITIAN}

Penelitian ini dilakukan di Kantor Pertanahan Kabupaten Merangin Provinsi Jambi, dimana yang menjadi kunci analisis dalam penelitian ini adalah pegawai pada Kantor Pertanahan Kabupaten Merangin sebanyak 60 orang. Penelitian ini menggunakan metode penelitian analisis deskriptif dan metode verifikatif. Metode analisis deskriptif adalah metode penelitian yang dilakukan untuk menggambarkan dan menjelaskan keadaan mengenai fakta-fakta dan sifat-sifat populasi berdasarkan data-data yang telah dikumpulkan. Sedangkan metode verifikatif adalah metode penelitian yang digunakan dalam upaya untuk menguji kebenaran hipotesis dengan menggunakan perhitungan statistik untuk menjawab tentang seberapa besar pengaruh variabel independent $(\mathrm{X})$ terhadap variabel dependent $(\mathrm{Z})$ dengan variabel intervening (Y). Teknik pengumpulan data dalam penelitian ini dengan mengumpulkan data melalui daftar pertanyaan yang telah dipersiapkan terlebih dahulu sesuai variabel penelitian yang ditujukan kepada responden yang berhubungan dengan disiplin, motivasi dan lingkungan kerja serta kinerja pegawai.

\section{Metode Analisis}

Analisis deskriptif dilaksanakan dengan menggunakan skala Likert yang dirancang untuk menilai sejauh mana subjek sertuju atau tidak setuju dengan pernyataan yang diajukan. Skala Likert digunakan untuk mengukur respon subjek kedalam 5 point, yaitu (5) Sangat Setuju; (4) Setuju; (3) Cukup Setuju; (2) Kurang Setuju; (1) Tidak Setuju 
Path Analysis

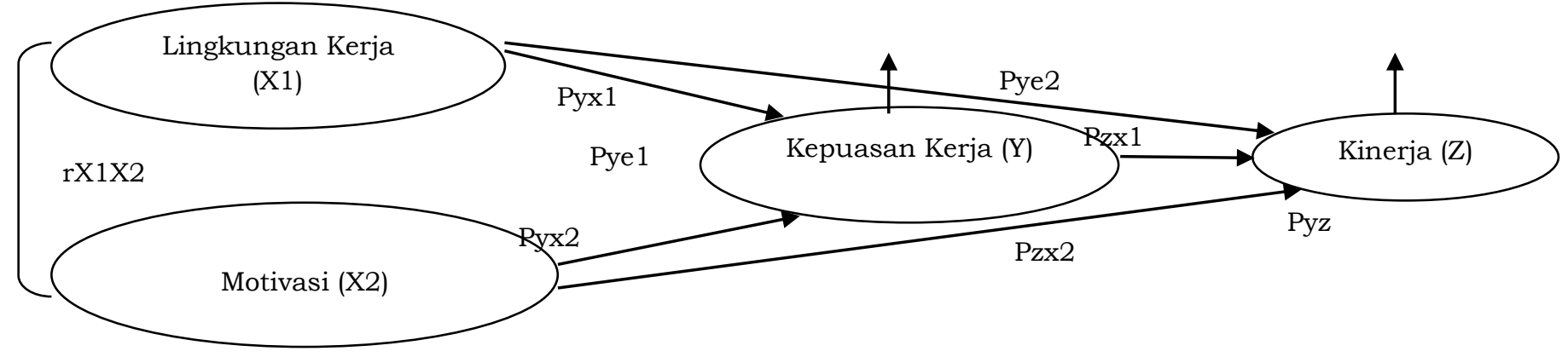

Gambar 1

Path Analysis

Keterangan: $\mathrm{X} 1$ = Lingkungan Kerja; X2 = Motivasi; $\mathrm{Y}=$ Kepuasan Kerja; Z = Kinerja

Penggunaan analisis jalur dalam penelitian ini untuk dapat melihat pengaruh langsung dan tidak langsung dari variabel independen terhadap variabel dependen. Path Analysis dikembangkan sebagai metode untuk mempelajari pengaruh secara langsung dan secara tidak langsung dari variabel bebas terhadap variabel tergantung. Analisis ini merupakan salah satu pilihan dalam rangka mempelajari ketergantungan sejumlah variabel di dalam model. Analisis ini merupakan metode yang baik untuk menerangkan apabila terdapat seperangkat data yang besar untuk dianalisis dan mencari hubungan kausal.

\section{Uji Validitas}

Validitas adalah suatu ukuran yang menunjukkan tingkat-tingkat kevalidan dan kesahihan suatu instrumen. Suatu instrumen yang valid atau sahih mempunyai validitas yang tinggi, sebaliknya instrumen yang kurang valid berarti memiliki validitas rendah. Sebuah instrumen dikatakan valid apabila dapat mengungkapkan data dari variabel yang diteliti secara tepat. Tinggi rendahnya instrumen menunjukkan sejauh mana data yang terkumpul tidak menyimpang dari gambaran tentang variabel yang dimaksud. Korelasi Product Moment dari Pearson, suatu indikator dikatakan valid apabila $\mathrm{N}=60$ dan $\alpha=0,05$ maka $\mathrm{r}$ tabel $=0,254$ dengan ketentuan ;

- Hasil $\mathrm{r}_{\text {hitung }}>\mathrm{r}_{\text {tabel }}(0,254)=$ valid

- Hasil $r_{\text {hitung }}<r_{\text {tabel }}(0,254)=$ tidak valid

\section{Uji Reliabilitas}

Reliabilitas adalah sesuatu instrumen cukup dapat dipercaya untuk digunakan sebagai alat pengumpul data karena instrumen tersebut sudah baik. Uji Reliabilitas dilakukan untuk mengetahui tingkat konsistensi hasil pengukuran bila dilakukan pengukuran ulang terhadap gejala dan alat ukur yang sama. Adapun metode perhitungan koefisien reliabilitas yang digunakan dalam penelitian ini adalah metode alpha crobach. Suatu instrumen dikatakan reliabel jika memberikan nilai cronbach's alpha $>0,60$, dan jika nilai cronbach's alpha $<0,60$ maka variabel tersebut tidak reliabel.

\section{Uji Simultan (Uji Statistik F)}

Untuk menguji pengaruh variabel bebas secara bersama-sama (simultan) terhadap variabel terikat, untuk uji F, kriteria uji yang dipakai adalah :

- $\mathrm{H}_{0}$ diterima bila $\mathrm{F} \leq \mathrm{F} \alpha$

- $\mathrm{H}_{0}$ ditolak bila $\mathrm{F}>\mathrm{F} \alpha$

$\mathrm{F} \alpha$ ditentukan oleh degree of freedom pembilang dan penyebut yaitu $\mathrm{V}_{1}=\mathrm{k}$ dan $\mathrm{V}_{2}=\mathrm{n}-\mathrm{k}-1$. Bila $\mathrm{H}_{0}$ diterima, maka diartikan sebagai tidak signifikannya suatu pengaruh dari variabel-variabel independen secara bersama-sama atas suatu variabel dependen dan penolakan $\mathrm{H}_{0}$ menunjukkan adanya 
pengaruh yang signifikan dari variabel-variabel independen secara bersama-sama terhadap suatu variabel independen.

\section{Uji Parsial (Uji t)}

Berdasarkan pengujian uji t, akan diperoleh hasil t hitung, kemudian dibandingkan dengan t tabel. Keputusan yang akan diambil adalah :

- H0 diterima jika - $\mathrm{t}(1-1 / 2 \alpha) \leq \mathrm{t} \leq \mathrm{t}(1-1 / 2 \alpha)$

- H0 ditolak jika $\mathrm{t}<\mathrm{t}(1-1 / 2 \alpha \alpha)$ atau $\mathrm{t}>\mathrm{t}(1-1 / 2 \alpha)$

Pengujian hipotesis dilakukan dengan uji dua pihak pada taraf signifikansi yang digunakan $5 \%$ dan $\mathrm{dk}=\mathrm{n}-\mathrm{k}-1$. Bila $\mathrm{H} 0$ ditolak dan sebaliknya $\mathrm{H} 1$ diterima artinya bahwa variabel bebas tersebut berpengaruh signifikan terhadap variabel terikat.

\section{HASIL DAN PEMBAHASAN \\ Pengujian Validitas}

Uji validitas digunakan untuk menguji sejauh mana ketepatan alat ukur dapat mengungkapkan konsep/kejadian yang diukur. Kuesioner dikatakan valid apabila $r$ hitung $>r$ tabel. Pernyataan dikatakan valid karena untuk masing-masing butir pernyataan mempunyai nilai diatas 0,254. Bila korelasi faktor positif dan besar nilainya 0,254 ke atas, maka faktor tersebut merupakan valid seperti yang tergambar dalam tabel berikut :

Tabel 1

Pengujian Validitas Lingkungan Kerja

\begin{tabular}{lllr}
\hline \multicolumn{1}{c}{ Instrumen } & Koefisien Korelasi (r hitung) & Signifikansi & Keterangan \\
\hline X11 & 0,265 & 0,254 & Valid \\
X12 & 0,555 & 0,254 & Valid \\
X13 & 0,732 & 0,254 & Valid \\
X14 & 0,547 & 0,254 & Valid \\
X15 & 0,504 & 0,254 & Valid \\
X16 & 0,575 & 0,254 & Valid \\
X17 & 0,681 & 0,254 & Valid \\
X18 & 0,696 & 0,254 & Valid \\
X19 & 0,623 & 0,254 & Valid \\
X110 & 0,423 & 0,254 & Valid \\
X111 & 0,472 & 0,254 & Valid \\
X112 & 0,427 & 0,254 & Valid \\
X113 & 0,407 & 0,254 & Valid \\
X114 & 0,341 & 0,254 & Valid \\
\hline
\end{tabular}

Sumber: data olahan

Tabel 2

Pengujian Validitas Motivasi

\begin{tabular}{lrrr}
\hline \multicolumn{1}{c}{ Instrumen } & Koefisien Korelasi (r hitung) & Signifikansi & Keterangan \\
\hline X21 & 0,315 & 0,254 & Valid \\
X22 & 0,769 & 0,254 & Valid \\
X23 & 0,628 & 0,254 & Valid \\
X24 & 0,734 & 0,254 & Valid \\
X25 & 0,255 & 0,254 & Valid \\
X26 & 0,585 & 0,254 & Valid \\
X27 & 0,454 & 0,254 & Valid \\
X28 & 0,787 & 0,254 & Valid \\
X29 & 0,831 & 0,254 & Valid \\
X210 & 0,765 & 0,254 & Valid \\
\hline
\end{tabular}

Sumber: data olahan 
Tabel 3

Pengujian Validitas Kepuasan Kerja

\begin{tabular}{|c|c|c|c|}
\hline Instrumen & Koefisien Korelasi (r hitung) & Signifikansi & Keterangan \\
\hline Y1 & a & 0,254 & Valid \\
\hline Y2 & 0,552 & 0,254 & Valid \\
\hline Y3 & 0,824 & 0,254 & Valid \\
\hline Y4 & 0,870 & 0,254 & Valid \\
\hline Y5 & 0,841 & 0,254 & Valid \\
\hline Y6 & 0,794 & 0,254 & Valid \\
\hline Y7 & 0,787 & 0,254 & Valid \\
\hline Y8 & 0,608 & 0,254 & Valid \\
\hline Y9 & 0,390 & 0,254 & Valid \\
\hline Y10 & 0,415 & 0,254 & Valid \\
\hline Y11 & 0,560 & 0,254 & Valid \\
\hline Y12 & 0,627 & 0,254 & Valid \\
\hline
\end{tabular}

Sumber: data olahan

Tabel 4

Pengujian Validitas Kinerja

\begin{tabular}{lrrr}
\hline \multicolumn{1}{c}{ Instrumen } & Koefisien Korelasi (r hitung) & Signifikansi & \multicolumn{2}{c}{ Keterangan } \\
\hline Z1 & 0,765 & 0,254 & Valid \\
Z2 Valid & Valid \\
Z3 & 0,728 & 0,254 & Valid \\
Z4 & 0,627 & 0,254 & Valid \\
Z5 & 0,647 & 0,254 & Valid \\
Z6 & 0,799 & 0,254 & Valid \\
Z7 & 0,644 & 0,254 & Valid \\
Z8 & 0,659 & 0,254 & Valid \\
Z9 & 0,724 & 0,254 & Valid \\
Z10 & 0,720 & 0,254 & Valid \\
Z11 & 0,723 & 0,254 & Valid \\
Z12 & 0,927 & 0,254 & Valid \\
Z13 & 0,825 & 0,254 & Valid \\
Z14 & 0,844 & 0,254 & Valid \\
Z15 & 0,795 & 0,254 & Valid \\
Z16 & 0,693 & 0,254 & 0,254 \\
\hline
\end{tabular}

Sumber: data olahan

\section{Pengujian Reliabilitas}

Tabel 5

Hasil Uji Reliabilitas terhadap Variabel Lingkungan Kerja, Motivasi, Kepuasan Kerja dan Kinerja Pada Kantor Pertanahan Kabupaten Merangin

\begin{tabular}{lrrr}
\hline \multicolumn{1}{c}{ Variabel } & \multicolumn{1}{c}{ Koefisien Variansi (alpha) } & \multicolumn{1}{c}{ r Product Moment (r tabel) } & Keterangan \\
\hline Lingkungan Kerja & 0,785 & 0,60 & Reliabel \\
Motivasi & 0,830 & 0,60 & Reliabel \\
Kepuasan Kerja & 0,876 & 0,60 & Reliabel \\
Kinerja & 0,941 & 0,60 & Reliabel \\
\hline
\end{tabular}

Sumber: data olahan

Koefisien variansi (alpha) untuk setiap variabel lebih besar dari angka $r$ tabel sebesar 0,60, maka dapat dikatakan bahwa seluruh variabel reliabel dan dapat dijadikan sebagai instrumen pengukuran. 
Tabel 6

Deskripsi Tingkat Lingkungan Kerja, Motivasi, Kepuasan Kerja dan Kinerja

\begin{tabular}{lllll}
\hline No. & Variabel & Total Skor & Rentang Skala & Hasil Hipotesis \\
\hline 1. & Lingkungan Kerja & 3136 & $2856-3527,9$ & Baik / Kondusif \\
2. & Motivasi & 2253 & $2040-2519,9$ & Baik / Tinggi \\
3. & Kepuasan Kerja & 2719 & $2448-3023,9$ & Baik / Puas \\
4. & Kinerja & 3778 & $3264-4031,9$ & Baik / Tinggi \\
\hline
\end{tabular}

Sumber: data olahan

Pada tabel 6 diatas terlihat bahwa lingkungan kerja berada pada rentang skala baik/kondusif, motivasi pada rentang skala baik/tinggi, kepuasan kerja pada rentang skala baik/puas, dan kinerja berada pada rentang skala yang baik/tinggi.

\section{Pengaruh Lingkungan Kerja terhadap Kepuasan Kerja}

Untuk menjawab hipotesis 2 sampai dengan 3 dilakukan pengujian dengan menggunakan program SPSS. Berdasarkan hasil perhitungan didapat hasil sebagai berikut ;

Tabel 7

Hasil Regresi Lingkungan Kerja dan Motivasi terhadap Kepuasan Kerja Pada Kantor Pertanahan Kabupaten Merangin

\begin{tabular}{|c|c|c|c|c|c|c|}
\hline \multirow{2}{*}{\multicolumn{2}{|c|}{ Model }} & \multicolumn{2}{|c|}{ Unstandardized Coefficients } & \multirow{2}{*}{$\frac{\text { Standardized Coefficients }}{\text { Beta }}$} & \multirow[b]{2}{*}{$\mathrm{t}$} & \multirow[b]{2}{*}{ Sig. } \\
\hline & & $\mathrm{B}$ & Std. Error & & & \\
\hline \multirow[t]{3}{*}{1} & (Constant) & 4.945 & 3.141 & & 1.575 & .121 \\
\hline & LINGKUNGAN KERJA & .131 & .073 & .141 & 1.789 & .079 \\
\hline & MOTIVASI & .894 & .089 & .792 & 10.090 & .000 \\
\hline
\end{tabular}

Sumber: data olahan

Pengaruh langsung dan tidak langsung lingkungan kerja terhadap kepuasan kerja adalah besarnya pengaruh langsung dan tidak langsung Lingkungan kerja (X1) terhadap Kepuasan kerja (Y);

1. Pengaruh langsung $\mathrm{X} 1$ terhadap $\mathrm{Y}$ $\mathrm{X} 1 \rightarrow \mathrm{Y}=(\mathrm{Pyx} 1)(\mathrm{Pyx} 1)=(0,141)(0,141)=0,019881=1,9881 \%$

2. Pengaruh tidak langsung X1 terhadap $\mathrm{Y}$ melalui $\mathrm{X} 2$ (Motivasi)

$\mathrm{X} 1{ }^{\prime} \Omega \mathrm{X} 2 \rightarrow \mathrm{Y}=(\mathrm{Pyx} 1)(\operatorname{rx} 1 \times 2)(\mathrm{Pyx} 2)=(0,141)(0,628)(0,792)=0,07013=7,013 \%$

3. Total pengaruh langsung dan tidak langsung $=1,9881 \%+7,013 \%=9,0011 \%$

Rincian diatas didapat pengaruh langsung lingkungan kerja ( X1) terhadap kepuasan kerja (Y) sebesar $1,9881 \%$, pengaruh tidak langsung sebesar 7,013\% dan pengaruh total sebesar 9,0011\%. Hal ini berarti bahwa lingkungan kerja berpengaruh terhadap kepuasan kerja.

\section{Pengaruh Motivasi terhadap Kepuasan Kerja}

Besarnya pengaruh langsung dan tidak langsung Motivasi (X2) terhadap Kepuasan kerja (Y).

1. Pengaruh langsung $\mathrm{X} 2$ terhadap $\mathrm{Y}$

$\mathrm{X} 2 \rightarrow \mathrm{Y}=(\mathrm{Pyx} 2)(\mathrm{Pyx} 2)=(0,792)(0,792)=0,627264=62,7264 \%$

2. Pengaruh tidak langsung $\mathrm{X} 2$ terhadap $\mathrm{Y}$ melalui $\mathrm{X} 1$

$\mathrm{X} 2{ }^{\prime} \Omega \mathrm{X} 1 \rightarrow \mathrm{Y}=(\mathrm{Pyx} 2)(\operatorname{rx} 1 \mathrm{x} 2)(\mathrm{Pyx} 1)=(0,792)(0,628)(0,141)=0,07013=7,013 \%$

3. Total pengaruh langsung dan tidak langsung $=62,7264 \%+7,013 \%=69,7394 \%$

Perhitungan diatas didapat pengaruh langsung motivasi (X2) terhadap kepuasan kerja (Y) sebesar $62,7264 \%$, pengaruh tidak langsung sebesar 7,013\%, dan pengaruh total sebesar 69,7394\%, ini menunjukkan bahwa motivasi berpengaruh signifikan terhadap kepuasan kerja pegawai Kantor Pertanahan Kabupaten Merangin.

\section{Pengaruh Lingkungan Kerja dan Motivasi secara bersama-sama terhadap Kepuasan Kerja \\ Besarnya pengaruh secara bersama-sama antara X1 dan X2 terhadap Y}


1. Pengaruh langsung $\mathrm{X} 1$ dan $\mathrm{X} 2$ terhadap $\mathrm{Y}$

$\mathrm{X} 1 \& \mathrm{X} 2 \rightarrow \mathrm{Y}=(\mathrm{Pyx} 1 . \mathrm{Pyx} 1)+(\mathrm{Pyx} 2 \cdot \mathrm{Pyx} 2)=1,9881 \%+62,7264 \%=64,7145 \%$

2. Pengaruh tidak langsung secara bersama-sama antara $\mathrm{X} 1$ dan $\mathrm{X} 2$ terhadap $\mathrm{Y}$

$\mathrm{X} 1 \& \mathrm{X} 2 \rightarrow \mathrm{Y}=(\mathrm{Pyx} 1)(\operatorname{rx} 1 \times 2)(\mathrm{Pyx} 2)+(\mathrm{Pyx} 2)(\operatorname{rx} 2 \mathrm{x} 1)(\mathrm{Pyx} 1)=7,013 \%+7,013 \%=14,026 \%$

3. Total pengaruh langsung dan tidak langsung $=64,7145 \%+14,026 \%=78,7405 \%$

Perhitungan diatas dapat disimpulkan bahwa total pengaruh langsung dan tidak langsung lingkungan kerja (X1) dan motivasi (X2) secara bersama-sama terhadap kepuasan kerja (Y) sebesar 78,7405 \%, dimana angka tersebut menjelaskan bahwa secara bersama-sama lingkungan kerja dan motivasi berpengaruh signifikan terhadap kepuasan kerja pegawai Kantor Pertanahan Kabupaten Merangin.

\section{Pengaruh Lingkungan Kerja terhadap Kinerja}

Untuk menjawab hipotesis 4 sampai dengan 5, dilakukan pengujian dengan menggunakan program SPSS. Berdasarkan hasil perhitungan didapat hasil sebagai berikut ;

Tabel 8

Hasil Regresi Lingkungan Kerja dan Motivasi terhadap Kinerja Pada Kantor Pertanahan Kabupaten Merangin

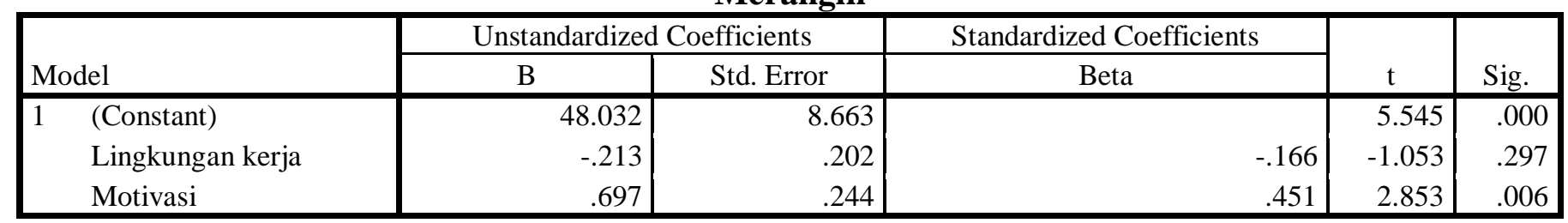

Sumber: data olahan

Besarnya pengaruh langsung dan tidak langsung Lingkungan kerja (X1) terhadap Kinerja (Z).

1. Pengaruh langsung $X 1$ terhadap $Z$ $\mathrm{X} 1 \rightarrow \mathrm{Z}=(\mathrm{Pzx} 1)(\mathrm{Pzx} 1)=(-0,166)(-0,166)=0,027556=2,7556 \%$.

2. Pengaruh tidak langsung $X 1$ terhadap $Z$ melalui $X 2$

$\mathrm{X} 1{ }^{\prime} \Omega \mathrm{X} 2 \rightarrow \mathrm{Z}=(\mathrm{Pzx} 1)(\operatorname{rx} 1 \times 2)(\mathrm{Pzx} 2)=(-0,166)(0,628)(0,451)=-0,0470158=-4,7015 \%$.

3. Total pengaruh langsung dan tidak langsung $=2,7556 \%+(-4,7015 \%)=-1,9459 \%$

Rincian diatas didapat pengaruh langsung lingkungan kerja (X1) terhadap kinerja (Z) sebesar 2,7556\%, pengaruh tidak langsung lingkungan kerja (X1) terhadap kinerja (Z) sebesar $-4,7015 \%$, dan total pengaruh secara langsung dan tidak langsung sebesar $-1,9459 \%$. Hal ini berarti bahwa lingkungan kerja berpengaruh tidak signifikan terhadap kinerja pegawai Kantor Pertanahan Kabupaten Merangin.

\section{Pengaruh Motivasi terhadap Kinerja}

Besarnya pengaruh langsung dan tidak langsung Motivsi (X2) terhadap Kinerja (Z)

1. Pengaruh langsung $\mathrm{X} 2$ terhadap $\mathrm{Z}$ $\mathrm{X} 2 \rightarrow \mathrm{Z}=(\mathrm{Pzx} 2)(\mathrm{Pzx} 2)=(0,451)(0,451)=0,203401=20,3401 \%$.

2. Pengaruh tidak langsung $X 2$ terhadap $Z$ melalui $X 1$

$\mathrm{X} 2{ }^{\prime} \Omega \mathrm{X} 1 \rightarrow \mathrm{Z}=(\mathrm{Pzx} 2)(\operatorname{rx} 1 \times 2)(\mathrm{Pzx} 1)=(0,451)(0,628)(-0,166)=-, 0470158=-4,7015 \%$.

3. Total pengaruh langsung dan tidak langsung $=20,3401 \%+(-4,7015 \%)=15,6386 \%$

Rincian diatas didapat pengaruh langsung motivasi (X2) terhadap kinerja (Z) sebesar 20,3401\%, pengaruh tidak langsung sebesar $-4,7015 \%$, dan total pengaruh langsung dan tidak langsung adalah sebesar $15,6386 \%$. Hal ini berarti bahwa motivasi berpengaruh signifikan terhadap kinerja pegawai Kantor Pertanahann Kabupaten Merangin.

\section{Pengaruh Lingkungan Kerja dan Motivasi secara bersama-sama terhadap Kinerja}

Besarnya pengaruh secara bersama-sama antara X1 dan X2 terhadap Z,

1. Pengaruh langsung $X 1$ dan $X 2$ terhadap $Z$

$\mathrm{X} 1 \& \mathrm{X} 2 \rightarrow \mathrm{Z}=(\mathrm{Pzx} 1 . \mathrm{Pzx} 1)+(\mathrm{Pzx} 2 . \mathrm{Pzx} 2)=2,7556 \%+20,3401 \%=23,0957 \%$ 
2. Pengaruh tidak langsung $X 1$ dan $X 2$ terhadap $Z$

$\mathrm{X} 1 \& \mathrm{X} 2 \rightarrow \mathrm{Z}=(\mathrm{Pzx} 1)(\operatorname{rx} 1 \mathrm{x} 2)(\mathrm{Pzx} 2)+(\mathrm{Pzx} 2)(\operatorname{rx} 2 \times 1)(\mathrm{Pzx} 1)=-4,7015 \%+(-4,7015 \%)=-9,403 \%$

3. Total pengaruh langsung dan tidak langsung $=23,0957 \%+(-9,403 \%)=13,6927 \%$

Perhitungan diatas dapat disimpukan bahwa total pengaruh langsung dan tidak langsung lingkungan kerja dan motivasi secara bersama-sama terhadap kinerja sebesar 13,6927\%, dimana angka tersebut menjelaskan bahwa lingkungan kerja dan motivasi secara bersama-sama berpengaruh signifikan terhadap kinerja pegawai pada Kantor Pertanahan Kabupaten Merangin.

\section{Pengaruh Kepuasan Kerja terhadap Kinerja}

Untuk menjawab hipotesis 6, dilakukan pengujian dengan menggunakan program SPSS. Berdasarkan hasil perhitungan didapat hasil sebagai berikut ;

\section{Tabel 9}

\section{Hasil Regresi Kepuasan Kerja terhadap Kinerja Pada Kantor Pertanahan Kabupaten Merangin}

\begin{tabular}{|c|c|c|c|c|c|}
\hline \multirow[b]{2}{*}{ Model } & \multicolumn{2}{|c|}{ Unstandardized Coefficients } & \multirow{2}{*}{$\begin{array}{c}\text { Standardized Coefficients } \\
\text { Beta } \\
\end{array}$} & \multirow[b]{2}{*}{$\mathrm{t}$} & \multirow[b]{2}{*}{ Sig. } \\
\hline & $\mathrm{B}$ & Std. Error & & & \\
\hline $1 \quad$ (Constant) & 38.424 & 7.527 & & 5.105 & .000 \\
\hline Kepuasan kerja & .542 & .165 & .396 & 3.280 & .002 \\
\hline
\end{tabular}

Sumber: data olahan

Besarnya pengaruh langsung $\mathrm{Y}$ terhadap $\mathrm{Z}$,

$\mathrm{Y} \rightarrow \mathrm{Z} \quad=(\mathrm{Pyz})(\mathrm{Pyz})=(0,396)(0,396)=0,156816=15,6816 \%$

Rincian diatas didapat pengaruh langsung kepuasan kerja (Y) terhadap kinerja (Z) sebesar 15,6816\%, hal ini berarti bahwa kepuasan kerja berpengaruh signifikan terhadap kinerja pegawai pada Kantor Pertanahan Kabupaten Merangin.

\section{Pengaruh Lingkungan Kerja dan Motivasi Terhadap Kinerja Melalui Kepuasan Kerja}

1. Besarnya pengaruh langsung $\mathrm{X} 1$ terhadap $\mathrm{Z}$ melalui $\mathrm{Y}$ adalah ; $=($ Pzx 1 $)($ Pyx 1$)($ Pzy $)=(-0,166)(0,141)(0,396)=-0,009268=-0,9268 \%$.

2. Besarnya pengaruh tidak langsung $X 1$ terhadap $Z$ melalui $X 2$ dan $Y$ adalah $=(\mathrm{Pzx} 1)(\mathrm{Pyx} 1)(\mathrm{rx} 1 x 2)(\mathrm{Pyx} 2)(\mathrm{Pzy})=(-0,166)(0,141)(0,628)(0,792)(0,396)=-0,004610=-0,461 \%$.

3. Total pengaruh langsung dan tidak langsung $=-0,9268 \%+(-0,4610 \%)=-, 3878 \%$.

Perhitungan diatas dapat disimpulkan bahwa lingkungan kerja terhadap kinerja melalui kepuasan kerja pengaruhnya langsung sebesar $-0,9268 \%$, pengaruh tidak langsungnya sebesar $-0,4610 \%$, dan total pengaruh secara langsung dan tidak langsung sebesar -1,3878\%, dimana angka tersebut menjelaskan bahwa lingkungan kerja melalui kepuasan kerja tidak memberikan sumbangan terhadap kinerja pegawai Kantor Pertanahan Kabupaten Merangin.

Besarnya pengaruh langsung dan tidak langsung motivasi terhadap kinerja melalui kepuasan kerja, yaitu ;

1. Besarnya pengaruh langsung $\mathrm{X} 2$ terhadap $\mathrm{Z}$ melalui $\mathrm{Y}$ adalah ; $=(\mathrm{Pzx} 2)(\mathrm{Pyx} 2)(\mathrm{Pzy})=(0,451)(0,792)(0,396)=0,141448=14,1448 \%$.

2. Besarnya pengaruh tidak langsung $\mathrm{X} 2$ terhadap $\mathrm{Z}$ melalui $\mathrm{X} 1$ dan $\mathrm{Y}$ adalah ; $=(\mathrm{Pzx} 2)(\mathrm{Pyx} 2)(\mathrm{rx} 1 x 2)(\mathrm{Pyx} 1)(\mathrm{Pzy})=(0,451)(0,792)(0,628)(0,141)(0,396)=0,012525=1,2525 \%$.

3. Besarnya pengaruh tidak langsung $\mathrm{X} 2$ terhadap $\mathrm{Z}$ melalui $\mathrm{X} 1$ dan $\mathrm{Y}$ adalah $=14,1448 \%+1,2525 \% .=15,3973 \%$.

Perhitungan diatas dapat disimpulkan bahwa motivasi terhadap kinerja melalui kepuasan kerja pengaruh langsungnya sebesar 14,1448\%, pengaruh tidak langsung sebesar 1,252495\%, dan total pengaruh secara langsung dan tidak langsung sebesar 15,3973\%.

Besarnya pengaruh lingkungan kerja dan motivasi terhadap kinerja melalui kepuasan kerja, yaitu ;

1. Besarnya pengaruh secara bersama-sama X1 dan X2 terhadap $\mathrm{Z}$ melalui $\mathrm{Y}$ adalah ; $=(\mathrm{Pzx} 1)(\mathrm{Pyx} 1)(\mathrm{Pzy})+(\mathrm{Pzx} 2)(\mathrm{Pyx} 2)(\mathrm{Pzy})=-0,9268 \%+14,1448 \%=13,218 \%$. 
2. Besarnya pengaruh tidak langsung $\mathrm{X} 1$ dan $\mathrm{X} 2$ terhadap $\mathrm{Z}$ melalui $\mathrm{Y}$ adalah ; $=(\mathrm{Pzx} 1)(\mathrm{Pyx} 1)(\mathrm{rx} 1 \mathrm{x} 2)(\mathrm{Pyx} 2)(\mathrm{Pzy})+(\mathrm{Pzx} 2)(\mathrm{Pyx} 2)(\mathrm{rx} 1 \mathrm{x} 2)(\mathrm{Pyx} 1)(\mathrm{Pzy})=-0,461 \%+1,252 \%=0,791 \%$

3. Total pengaruh langsung dan tidak langsung adalah $=13,218 \%+0,7914 \%=14,0094 \%$.

Perhitungan diatas dapat disimpulkan bahwa lingkungan kerja dan motivasi terhadap kinerja melalui kepuasan kerja pengaruhnya langsung sebesar $13,218 \%$, pengaruh tidak langsung sebesar $0,7914 \%$, dan total pengaruh langsung dan tidak langsung sebesar 14,0094\%, dimana angka tersebut menjelaskan bahwa lingkungan kerja dan motivasi melalui kepuasan kerja berpengaruh signifikan terhadap kinerja pegawai.

\section{Pengujian Hipotesis Pertama}

Dari hasil penelitian yang telah dilakukan, karakteristik lingkungan kerja, motivasi, kepuasan kerja dan kinerja adalah sebagai berikut ;

a. Lingkungan kerja dengan nilai 3136 jika dilihat pada rentang skala yaitu 2856 - 3527,9, artinya responden setuju bahwa lingkungan kerja baik/kondusif, dan sesuai dengan hipotesis awal yang mengatakan lingkungan kerja diduga baik/kondusif.

b. Motivasi dengan nilai 2253 berada pada rentang skala 2040 - 2519,9, artinya responden setuju bahwa motivasi baik/tinggi, dan sesuai dengan hipotesis awal yang mengatakan motivasi diduga baik/tinggi.

c. Kepuasan kerja dengan nilai 2719 berada pada rentang skala 2448 - 3023,9, artinya responden setuju bahwa kepuasan kerja baik/puas, dan sesuai dengan hipotesis awal yang mengatakan kepuasan kerja diduga baik/puas.

d. Kinerja dengan nilai 3778 berada pada rentang skala 3264 - 4031,9, artinya responden setuju bahwa kinerja baik/tinggi, dan sesuai dengan hipotesis awal yang mengatakan kinerja diduga baik/tinggi.

\section{Pengujian Hipotesis Kedua}

Hasil pengujian hipotesis yang dilakukan pada variabel lingkungan kerja terhadap kepuasan kerja yang dilihat dari nilai t hitung yaitu sebesar 1,789 dengan sig. sebesar 0,079, sedangkan t tabel sebesar 2,003241, berarti hipotesis ditolak. Pengaruh langsung lingkungan kerja terhadap kepuasan kerja sebesar $7,013 \%$ dan pengaruh tidak langsung sebesar $1,9881 \%$. Hasil pengujian yang dilakukan pada variabel motivasi terhadap kepuasan kerja menunjukkan bahwa motivasi terbukti memiliki pengaruh yang signifikan terhadap kepuasan kerja dengan nilai t hitung sebesar 10,090 dengan sig. sebesar 0,000, sedangkan $t$ tabel sebesar 2,003241, berarti t hitung $>\mathrm{t}$ tabel. Hal ini berarti $\mathrm{H} 0$ ditolak dan $\mathrm{H} 1$ diterima, artinya ada pengaruh signifikan dari motivasi terhadap kepuasan kerja. Pengaruh langsung motivasi terhadap kepuasan kerja adalah sebesar $62,7264 \%$, dan pengaruh tidak langsung sebesar 7,013\%, sehingga total pengaruh langsung dan tidak langsung sebesar 69,7394\%.

\section{Pengujian Hipotesis Ketiga}

Hasil pengujian yang dilakukan terhadap variabel lingkungan kerja dan motivasi secara bersamasama terhadap kepuasan kerja menunjukkan bahwa lingkungan kerja dan motivasi terbukti memiliki pengaruh yang signifikan terhadap kepuasan kerja, dimana uji $\mathrm{F}$ menunjukkan nilai $\mathrm{F}$ hitung sebesar 105,424, dengan sig. sebesar 0,000, sedangkan F tabel sebesar 2,769431. Hal ini berarti bahwa F hitung $>\mathrm{F}$ tabel, artinya H0 ditolak dan $\mathrm{H} 1$ diterima. Besarnya pengaruh langsung lingkungan kerja dan motivasi secara bersama-sama terhadap kepuasan kerja adalah sebesar $64,7145 \%$, dan pengaruh tidak langsung sebesar 14,026\%, sehingga total pengaruh langsung dan tidak langsung sebesar 78,7405\%.

\section{Pengujian Hipotesis Keempat}

Hasil pengujian hipotesis yang dilakukan pada variabel lingkungan kerja terhadap kinerja yang dilihat dari nilai t hitung sebesar -1,053 sedangkan t tabel sebesar 2,003241, sehingga H0 diterima dan H1 ditolak. Pengaruh langsung lingkungan kerja terhadap kinerja sebesar 2,7556\%, dan pengaruh tidak langsung sebesar $-4,7015 \%$. Hasil perhitungan didadapat bahwa motivasi berpengaruh signifikan terhadap kinerja dengan nilai t hitung sebesar 2,853, dengan sig. sebesar 0,006, sedangkan nilai t tabel sebesar 2,003241, dimana $\mathrm{t}$ hitung $>\mathrm{t}$ tabel yang berarti $\mathrm{H} 0$ ditolak dan $\mathrm{H} 1$ diterima. Hal ini berarti bahwa motivasi 
berpengaruh terhadap kinerja pegawai, dimana besarnya pengaruh langsung sebesar 20,3401\%, dan pengaruh tidak langsung sebesar - 4,7015\%.

\section{Pengujian Hipotesis Kelima}

Hasil pengujian yang dilakukan terhadap variabel lingkungan kerja dan motivasi secara bersamasama terhadap kinerja menunjukkan bahwa lingkungan kerja dan motivasi secara bersama-sama terbukti memiliki pengaruh signifikan terhadap kinerja. Perhitungan diketahui bahwa $\mathrm{F}$ hitung menunjukkan nilai sebesar 4,519, dengan sig. sebesar 0,015, sedangkan F tabel menunjukkan angka sebesar 2,769431. Hal ini berarti $\mathrm{F}$ hitung $>\mathrm{F}$ tabel, artinya $\mathrm{H} 0$ ditolak dan $\mathrm{H} 1$ diterima. Besarnya pengaruh langsung adalah sebesar $23,0957 \%$, dan pengaruh tidak langsung sebesar $9,403 \%$.

\section{Pengujian Hipotesis Keenam}

Hasil pengujian menunjukkan bahwa variabel kepuasan kerja berpengaruh signifikan terhadap kinerja yang ditunjukkan oleh nilai t hitung sebesar 3,280, dengan sig. sebesar 0,002, sedangkan nilai t tabel sebesar 2,003241, dimana $t$ hitung $>\mathrm{t}$ tabel yang berarti $\mathrm{H} 0$ ditolak dan $\mathrm{H} 1$ diterima. Hal ini menunjukkan bahwa kepuasan kerja berpengaruh sgnifikan terhadap kinerja pegawai, dimana besarnya pengaruh langsung sebesar $15,6816 \%$.

\section{Pengujian Hipotesis Ketujuh}

Hasil pengujian yang dilakukan terhadap variabel lingkungan kerja dan motivasi secara bersamasama terhadap kinerja melalui kepuasan kerja menunjukkan bahwa lingkungan kerja dan motivasi secara bersama-sama terbukti memiliki pengaruh signifikan terhadap kinerja melalui kepuasan kerja. Perhitungan diketahui bahwa $\mathrm{F}$ hitung menunjukkan nilai sebesar 4,330, dengan sig. sebesar 0,008, sedangkan $\mathrm{F}$ tabel menunjukkan angka sebesar 2,769431. Hal ini berarti F hitung $>\mathrm{F}$ tabel, artinya H0 ditolak dan H1 diterima. Besarnya pengaruh langsung adalah sebesar 13,218\%, dan pengaruh tidak langsung sebesar $0,7914 \%$.

Perhitungan data menggunakan program SPSS terhadap hasil kuesioner tentang lingkungan kerja, didapat koefisien korelasi ( $r$ hitung) semuanya lebih besar dari $r$ tabel $(0,254)$, dengan demikian sebanyak 14 item pernyataan untuk variabel lingkungan kerja dinyatakan valid semua. Sedangkan untuk koefisien variansi (alpha) sebesar 0,785, lebih besar dari $\mathrm{r}$ product moment ( $\mathrm{r}$ tabel) sebesar 0,60, dengan demikian variabel lingkungan kerja dinyatakan reliabel dan dapat dijadikan sebagai instrumen pengukuran.Berdasarkan 10 item pernyataan dengan skor total jawaban responden sebesar 2253 dan ratarata sebesar 225,3, maka motivasi termasuk dalam kategori baik/tinggi.

Perhitungan data menggunakan program SPSS terhadap hasil kuesioner tentang motivasi, didapat koefisien korelasi ( $\mathrm{r}$ hitung) semuanya lebih besar dari $\mathrm{r}$ tabel $(0,254)$, dengan demikian sebanyak 10 item pernyataan untuk variabel motivasi dinyatakan valid semua. Sedangkan untuk koefisien variansi (alpha) sebesar 0,830, lebih besar dari $\mathrm{r}$ product moment ( $\mathrm{r}$ tabel) sebesar 0,60, dengan demikian variabel motivasi dinyatakan reliabel dan dapat dijadikan sebagai instrumen pengukuran. Berdasarkan 12 item pernyataan dengan skor total jawaban responden sebesar 2719 dan rata-rata sebesar 226,5, maka kepuasan kerja termasuk dalam kategori baik/puas.

Perhitungan data menggunakan program SPSS terhadap hasil kuesioner tentang kepuasan kerja, didapat koefisien korelasi ( $r$ hitung) semuanya lebih besar dari $r$ tabel $(0,254)$, dengan demikian sebanyak 12 item pernyataan untuk variabel kepuasan kerja dinyatakan valid semua. Sedangkan untuk koefisien variansi (alpha) sebesar 0,876, lebih besar dari $\mathrm{r}$ product moment ( $\mathrm{r}$ tabel) sebesar 0,60, dengan demikian variabel kepuasan kerja dinyatakan reliabel dan dapat dijadikan sebagai instrumen pengukuran. Berdasarkan 16 item pernyataan dengan skor total jawaban responden sebesar 3778 dan rata-rata sebesar 236,1, maka kinerja termasuk dalam kategori baik/tinggi. Perhitungan data menggunakan program SPSS terhadap hasil kuesioner tentang kinerja, didapat koefisien korelasi ( $\mathrm{r}$ hitung) semuanya lebih besar dari $\mathrm{r}$ tabel $(0,254)$, dengan demikian sebanyak 16 item pernyataan untuk variabel kinerja dinyatakan valid semua. Sedangkan untuk koefisien variansi (alpha) sebesar 0,941, lebih besar dari $\mathrm{r}$ product moment ( $\mathrm{r}$ tabel) sebesar 0,60, dengan demikian variabel kinerja dinyatakan reliabel dan dapat dijadikan sebagai instrumen pengukuran. 


\section{Pengaruh Lingkungan Kerja Terhadap Kepuasan Kerja}

Lingkungan kerja berpengaruh tidak signifikan terhadap kepuasan kerja, dimana terjadinya peningkatan ataupun penurunan tingkat kepuasan kerja tidak dipengaruhi secara langsung oleh lingkungan kerja. Lingkungan kerja yang baik tidak secara langsung meningkatkan kepuasan kerja pegawai. Karena pegawai merasa puas bukan karena lingkungan kerja yang baik, tetapi ada faktor lain yang membuat para pegawai merasa puas.

\section{Pengaruh Motivasi Terhadap Kepuasan Kerja}

Motivasi berpengaruh positif dan signifikan terhadap kepuasan kerja. Pengaruh langsung motivasi terhadap kepuasan kerja adalah sebesar $62,7264 \%$, dan pengaruh tidak langsung sebesar 7,013\%, sehingga total pengaruh langsung dan tidak langsung sebesar $69,7394 \%$. Dengan demikian peningkatan motivasi akan meningkatkan juga kepuasan kerja. Motivasi akan memberikan kepuasan kerja para pegawai. Semakin tinggi motivasi yang diberikan kepada para pegawai, maka semakin meningkat juga kepuasan kerja para pegawai. Sebaliknya jika pimpinan kurang bisa memberikan motivasi kepada para pegawai, maka pegawai merasa tidak puas dalam bekerja.

\section{Pengaruh Lingkungan Kerja dan Motivasi Secara Bersama-sama Terhadap Kepuasan Kerja}

Lingkungan kerja dan motivasi secara bersama - sama berpengaruh positif dan signifikan terhadap kepuasan kerja. Besarnya pengaruh langsung lingkungan kerja dan motivasi secara bersama-sama terhadap kepuasan kerja adalah sebesar $64,7145 \%$, dan pengaruh tidak langsung sebesar $14,026 \%$, sehingga total pengaruh langsung dan tidak langsung sebesar 78,7405\%. Secara bersama-sama jika lingkungan kerja dan motivasi meningkat, maka kepuasan kerja para pegawai juga meningkat, dan sebaliknya jika secara bersama-sama lingkungan kerja dan motivasi menurun, maka kepuasan kerja para pegawai juga akan menurun.

\section{Pengaruh Lingkungan Kerja Terhadap Kinerja}

Lingkungan kerja berpengaruh tidak signifikan terhadap kinerja, dimana pengaruh langsung lingkungan kerja terhadap kinerja sebesar $2,7556 \%$, dan pengaruh tidak langsung sebesar $-4,7015 \%$. Hal ini dapat diartikan bahwa terjadinya peningkatan ataupun penurunan kinerja tidak dipengaruhi secara langsung oleh lingkungan kerja. Lingkungan kerja yang baik tidak secara langsung meningkatkan kinerja pegawai. Karena pegawai meningkat kinerjanya bukan karena lingkungan kerja yang baik, tetapi ada faktor lain yang membuat para pegawai meningkat kinerjanya.

\section{Pengaruh Motivasi Terhadap Kinerja}

Motivasi berpengaruh positif terhadap kinerja, dimana besarnya pengaruh langsung sebesar $20,3401 \%$, dan pengaruh tidak langsung sebesar $-4,7015 \%$. Dengan demikian peningkatan motivasi akan meningkatkan juga kinerja pegawai. Motivasi akan memberikan peningkatan kinerja pegawai. Semakin tinggi motivasi yang diberikan kepada para pegawai, maka semakin tinggi juga kinerja pegawai. Sebaliknya semakin menurun motivasi yang diberikan kepada para pegawai, maka akan menurun juga kinerja pegawai.

\section{Pengaruh Lingkungan Kerja dan Motivasi Secara Bersama-sama Terhadap Kinerja}

Lingkungan kerja dan motivasi secara bersama-sama terbukti memiliki pengaruh positif terhadap kinerja. Besarnya pengaruh langsung adalah sebesar 23,0957\%, dan pengaruh tidak langsung sebesar 9,403\%. Secara bersama-sama jika lingkungan kerja dan motivasi meningkat, maka kinerja para pegawai juga meningkat, dan sebaliknya jika secara bersama-sama lingkungan kerja dan motivasi menurun, maka kinerja para pegawai juga akan menurun.

\section{Pengaruh Kepuasan Kerja Terhadap Kinerja}

Kepuasan kerja berpengaruh positif terhadap kinerja, besarnya pengaruh langsung sebesar $15,6816 \%$. Semakin meningkat kepuasan kerja maka semakin meningkat pula kinerja pegawai. Pegawai dengan tingkat kepuasan kerja yang tinggi akan mampu bekerja dengan baik tanpa adanya beban atau 
tekanan. Bekerja menjadi hal yang menyenangkan, dan pegawai yang merasa puas akan berusaha dengan maksimal dan meningkatkan kinerja.

\section{Pengaruh Lingkungan Kerja dan Motivasi Terhadap Kinerja Melalui Kepuasan Kerja}

Lingkungan kerja dan motivasi secara bersama-sama terbukti memiliki pengaruh positif terhadap kinerja melalui kepuasan kerja. Besarnya pengaruh langsung adalah sebesar 13,218\%, dan pengaruh tidak langsung sebesar $0,7914 \%$. Hasil ini menunjukkan bahwa kepuasan kerja memediasi hubungan antara lingkungan kerja dan motivasi terhadap kinerja pegawai. Kinerja pegawai akan maksimal dan terus meningkat yang dipengaruhi oleh puasnya pegawai atas lingkungan kerja yang baik dan motivasi yang tinggi

\section{SIMPULAN}

Berdasarkan hasil penelitian yang telah dilakukan tentang pengaruh lingkungan kerja dan motivasi terhadap kepuasan kerja dan dampaknya terhadap kinerja pegawai pada Kantor Pertanahan Kabupaten Merangin, dapat diperoleh kesimpulan sebagai berikut ;

1. Gambaran lingkungan kerja berada pada kategori baik/kondusif, motivasi pada kategori baik/tinggi, kepuasan kerja pada kategori baik/puas, dan kinerja pegawai pada Kantor Pertanahan Kabupaten Merangin berada pada kategori baik/tinggi.

2. Lingkungan kerja berpengaruh tidak signifikan terhadap kepuasan kerja, dimana terjadinya peningkatan ataupun penurunan tingkat kepuasan kerja tidak dipengaruhi secara langsung oleh lingkungan kerja. Lingkungan kerja yang baik tidak secara langsung meningkatkan kepuasan kerja pegawai. Karena pegawai merasa puas bukan karena lingkungan kerja yang baik, tetapi ada faktor lain yang membuat para pegawai merasa puas.

3. Motivasi berpengaruh positif dan signifikan terhadap kepuasan kerja. Pengaruh langsung motivasi terhadap kepuasan kerja adalah sebesar $62,7264 \%$, dan pengaruh tidak langsung sebesar 7,013\%, sehingga total pengaruh langsung dan tidak langsung sebesar 69,7394\%. Dengan demikian peningkatan motivasi akan meningkatkan juga kepuasan kerja. Semakin tinggi motivasi yang diberikan kepada para pegawai, maka semakin meningkat juga kepuasan kerja para pegawai. Sebaliknya jika pimpinan kurang bisa memberikan motivasi kepada para pegawai, maka pegawai merasa tidak puas dalam bekerja.

4. Lingkungan kerja dan motivasi secara bersama-sama berpengaruh positif terhadap kepuasan kerja. Besarnya pengaruh langsung lingkungan kerja dan motivasi secara bersama-sama terhadap kepuasan kerja adalah sebesar $64,7145 \%$, dan pengaruh tidak langsung sebesar 14,026\%, sehingga total pengaruh langsung dan tidak langsung sebesar 78,7405\%. Secara bersama-sama jika lingkungan kerja dan motivasi meningkat, maka kepuasan kerja para pegawai juga meningkat, dan sebaliknya jika secara bersama-sama lingkungan kerja dan motivasi menurun, maka kepuasan kerja para pegawai juga akan menurun.

5. Lingkungan kerja berpengaruh tidak signifikan terhadap kinerja, dimana terjadinya peningkatan ataupun penurunan kinerja tidak dipengaruhi secara langsung oleh lingkungan kerja. Lingkungan kerja yang baik tidak secara langsung meningkatkan kinerja pegawai. Karena pegawai meningkat kinerjanya bukan karena lingkungan kerja yang baik, tetapi ada faktor lain yang membuat para pegawai meningkat kinerjanya.

6. Motivasi berpengaruh positif terhadap kinerja, dimana besarnya pengaruh langsung sebesar 20,3401\%, dan pengaruh tidak langsung sebesar $-4,7015 \%$. Semakin tinggi motivasi yang diberikan kepada para pegawai, maka semakin tinggi juga kinerja pegawai. Sebaliknya semakin menurun motivasi yang diberikan kepada para pegawai, maka akan menurun juga kinerja pegawai.

7. Lingkungan kerja dan motivasi secara bersama-sama terbukti memiliki pengaruh positif terhadap kinerja. Besarnya pengaruh langsung adalah sebesar 23,0957\%, dan pengaruh tidak langsung sebesar 9,403\%. Secara bersama-sama jika lingkungan kerja dan motivasi meningkat, maka kinerja para pegawai juga meningkat, dan sebaliknya jika secara bersama-sama lingkungan kerja dan motivasi menurun, maka kinerja para pegawai juga akan menurun. 
8. Kepuasan kerja berpengaruh positif terhadap kinerja, besarnya pengaruh langsung sebesar 15,6816\%. Semakin meningkat kepuasan kerja maka semakin meningkat pula kinerja pegawai. Pegawai dengan tingkat kepuasan kerja yang tinggi akan mampu bekerja dengan baik tanpa adanya beban atau tekanan. Bekerja menjadi hal yang menyenangkan, dan pegawai yang merasa puas akan berusaha dengan maksimal dan meningkatkan kinerja.

9. Lingkungan kerja dan motivasi secara bersama-sama terbukti memiliki pengaruh positif terhadap kinerja melalui kepuasan kerja. Besarnya pengaruh langsung adalah sebesar 13,218\%, dan pengaruh tidak langsung sebesar $0,7914 \%$. Kepuasan kerja memediasi hubungan antara lingkungan kerja dan motivasi terhadap kinerja pegawai. Kinerja pegawai akan maksimal dan terus meningkat yang dipengaruhi oleh puasnya pegawai atas lingkungan kerja yang baik dan motivasi yang tinggi

\section{DAFTAR PUSTAKA}

Adisetiawan, R., 2014, Performance Mahasiswa Fakultas Ekonomi Universitas Batanghari, Jurnal Ilmiah Universitas Batanghari Jambi, 14(3), 1-10

Adisetiawan, R., 2013, Kajian Persepsi Pemilik Usaha Kecil dan Menengah (UKM) Terhadap Laporan Keuangan, Jurnal Ilmiah Universitas Batanghari Jambi, 13(4), 162-173

Handoko, T. Hany, 2001, Manajemen Sumber Daya Manusia, BPE, Yogyakarta.

Hasibuan, M.S.P, 2008, Manajemen Sumber Daya Manusia, PT. Bumi Aksara, Jakarta.

Notoatmodjo, Soekidjo, 2009, Pengembangan Sumber Daya Manusia, PT. Rineka Cipta, Jakarta.

Prabu Mangkunegara, 2010, Perilaku dan Budaya Organisasi, PT. Refika Aditama, Bandung.

Simamora, H, 2006, Manajemen Sumber Daya Manusia, Edisi Ketiga, STIE, YKPN, Yogyakarta.

Sedarmayanti, 2001, Sumber Daya Manusia dan Produktivitas Kerja, Mandar Maju, Bandung.

Sofyandi, H, 2008, Manajemen Sumber Daya Manusia, Graha Ilmu, Yogyakarta. 